\title{
The up-regulation of pro-apoptotic signalling systems in peripheral blood lymphocytes of malnourished patients with pancreatic cancer after preoperative enteral immune-enhancing diet (immunonutrition)
}
Aktywacja proapoptotycznych szlaków sygnałowych w limfocytach krwi obwodowej niedożywionych chorych na raka trzustki po przedoperacyjnym dojelitowym żywieniu wspomagającym odporność (immunonutrition)

\author{
Robert Słotwiński ${ }^{12}$, Waldemar L Olszewski ${ }^{13}$, Maciej Słodkowski ${ }^{4}$, Gustaw Lech ${ }^{4}$, Marzanna Zaleska $^{1}$, \\ Sylwia Kędziora², Sylwia M. Słotwińska5 ${ }^{5}$, Ireneusz W. Krasnodębski ${ }^{4}$
1Department of Surgical Research and Transplantology, Medical Research Centre, Polish Academy of Sciences, Warsaw, Poland 2Department of Immunology and Nutrition, Medical University of Warsaw, Poland
3The Norwegian Radium Hospital, Oslo, Norway
4Department of General, Gastroenterological and Oncological Surgery, Medical University of Warsaw, Poland \\ ${ }^{5}$ Department of Conservative Dentistry, Medical University of Warsaw, Poland
}

Przegląd Gastroenterologiczny 2011; 6 (3): 154-159 DOI: $10.5114 / p g .2011 .22800$

Key words: apoptosis, pancreatic cancer surgery, immunonutrition.

Słowa kluczowe: apoptoza, chirurgia raka trzustki, immunonutrition.

\begin{abstract}
Address for correspondence: Prof. Robert Słotwiński MD, PhD, Department of Surgical Research and Transplantology, Medical Research
\end{abstract} Centre, 5 Pawińskiego, 02-106 Warsaw, Poland, tel. +48 2266853 16, fax +48 2266853 34, e-mail: slotwinski@cmdik.pan.pl

\begin{abstract}
Introduction: Pancreatic cancer surgery is one of the most invasive operations in upper abdominal surgery, with a high incidence of postoperative complications. Extensive tissue trauma and malnutrition results in disorders of programmed cell death influencing the patient's susceptibility to infections. The attempt to correct the postoperative immune disorders by introducing preoperative or postoperative immunonutrition is a promising way of improving outcome after pancreatic surgery.

Aim: To investigate the influence of surgical trauma and immunonutrition on the changes of apoptotic signalling pathways, randomized studies were performed in patients after pancreatic cancer surgery receiving preoperative standard or enteral immunonutrition.

Material and methods: The expression of TNFRI/CD120a, Fas/CD95 and Bcl-2 in lymphocytes was assessed by flow cytometry before and on day 1, 3 and 7 after surgery. The percentage of Fas (CD95+/CD3-) and TNFRI (CD120a) positive lymphocytes in the whole group of pancreatic cancer patients was significantly higher before as well as after surgery. The percentage of Bcl-2-positive lymphocytes was significantly
\end{abstract}

\section{Streszczenie}

Wstęp: Wycięcie raka trzustki jest jedną z najbardziej inwazyjnych operacji w obrębie górnego piętra jamy brzusznej, obarczoną dużym odsetkiem powikłań pooperacyjnych. Rozległy uraz tkanek i niedożywienie powodują zaburzenia programowanej śmierci (apoptozy) komórek układu odpornościowego, zwiększając wrażliwość chorych na zakażenia. Próby korekcji pooperacyjnych zaburzeń odporności za pomocą przed- lub pooperacyjnego żywienia typu immunonutrition są obiecującym sposobem poprawy wyników chirurgicznego leczenia raka trzustki.

Cel: W celu zbadania wpływu rozległego urazu operacyjnego i żywienia typu immunonutrition na zmiany ekspresji wybranych białek szlaków sygnałowych związanych z apoptozą wykonano badania $z$ randomizacją $u$ chorych po wycięciu raka trzustki otrzymujących przedoperacyjne dojelitowe żywienie standardowe lub immunonutrition.

Materiat i metody: Ekspresję TNFRI/CD120a, Fas/CD95 i Bcl-2 w limfocytach krwi obwodowej badano za pomocą cytometrii przepływowej przed operacją oraz w 1., 3. i 7. dniu po operacji. W całej grupie chorych na raka trzustki odsetek limfocytów Fas (CD95 $\left.{ }^{+} / \mathrm{CD}^{-}\right)$i TNFRI (CD120a) pozytywnych był istotnie 
decreased on day 1 and 7 after surgery. In comparison to standard nutrition, preoperative immunonutrition significantly increased the percentage of CD95 and TNFRI positive lymphocytes after surgery.

Results: Our studies revealed the up-regulation of pro-apoptotic signalling systems in peripheral blood lymphocytes of malnourished patients with pancreatic cancer. These pathological alterations in expression of apoptotic signalling pathway proteins may increase lymphocyte dysfunction and immune system suppression, especially after pancreatic resection. Preoperative enteral immunonutrition has a modulatory effect on apoptotic signalling pathways.

\section{Introduction}

Extensive tissue trauma and malnutrition result in disorders of programmed cell death influencing the patient's susceptibility to infections. This refers mainly to malnourished patients after extensive surgery for pancreatic cancer. Pancreaticoduodenectomy is one of the most invasive operations in upper abdominal surgery, with a high incidence of postoperative complications [1-3]. The attempt to correct postoperative immune disorders by introducing preoperative or postoperative immunonutrition is a promising way of improving the outcome after pancreatic surgery. However, the mechanisms underlying immune system suppression (e.g. decrease in the number of lymphocytes) and the mechanisms of correcting postoperative immune disorders (e.g. by regulation of lymphocyte apoptosis) using this type of nutrition are still unclear. It has recently become clearer that dietary polyunsaturated fatty acids (PUFAs) and some of their synthesized derivatives are able to modulate the molecular pathways involved in apoptosis [4]. Interestingly, the decreased $\mathrm{Bcl}-2$ anti-apoptotic protein level in pancreatic cancer cells incubated with omega-3 fatty acid enhanced media suggests mitochondrial directed apoptosis [5]. Glutamine can protect human T-cells from apoptosis by up-regulating glutathione, $\mathrm{BCl}-2$ and CD45RO anti-apoptotic protein expression in lymphocytes and down-regulation of the expression of caspase-3, Fas (CD95) and Fas ligand pro-apoptotic proteins [6]. In addition, an experimental study revealed that enrichment of the diet with fish oil/DHA (docosahexaenoic acid) may reduce the inflammation after tissue damage [7]. Resolvin D1 and protectin D1, DHA-derived lipid mediators, are involved in these mechanisms. In a model of mouse peritonitis, intraperitoneal delivery of protectin D1 before zymosan A reduced the number of neutrophils and levels of pro-inflammatory cytokines and chemokines [8]. zwiększony zarówno przed operacją, jak i po. Odsetek limfocytów Bcl-2 pozytywnych był istotnie zmniejszony w 1. i 7 . dniu po operacji. W porównaniu z żywieniem standardowym przedoperacyjne immunonutrition istotnie zwiększało odsetek limfocytów CD95 i TNFRI pozytywnych po operacji.

Wyniki: Wyniki badań wskazują na aktywację proapoptotycznych szlaków sygnałowych w limfocytach krwi obwodowej niedożywionych chorych na raka trzustki. Te patologiczne zmiany w ekspresji białek szlaków sygnałowych związanych z apoptozą mogą zwiększać zaburzenia funkcji limfocytów i pogłębiać supresję układu odpornościowego, zwłaszcza po wycięciu trzustki. Przedoperacyjne dojelitowe żywienie typu immunonutrition ma modulujący wpływ na szlaki sygnałowe związane z apoptozą.

\section{Aim}

The purpose of our study was to investigate the influence of surgical trauma and enteral immunonutrition versus enteral standard nutrition on the changes of apoptotic signalling pathways. The expression of $\mathrm{BCl}-2$, TNFR1/CD120a and Fas/CD95 was measured in peripheral blood lymphocytes.

\section{Material and methods}

Fifty out of 72 patients operated on for pancreatic cancer were randomized (by using numbered sealed envelopes stratified by the surgeon) to receive either the enteral standard diet (group I - 24 patients, mean age $62.5 \pm 9.2$ years) or the immune-enhancing enteral diet (group II -26 patients, mean age $61.8 \pm 8.7$ years). After full clinical diagnostic procedures (image and laboratory tests), all patients were operated on for resection of the head of the pancreas (Whipple's pancreaticoduodenectomy). Histopathological examination confirmed the diagnosis.

The present investigation did not include patients with early enteral or parenteral postoperative nutrition, early serious post-operative infectious complications, with unresectable pancreatic cancer, those who had transplantation of organs, patients treated with chemo- or radiotherapy or immunosuppressors, patients with autoimmune diseases, with diabetes type 1 (insulin-dependant), chronic respiratory insufficiency (chronic obstructive pulmonary disease), cardiovascular insufficiency, and kidney and liver diseases (biopsyproven cirrhosis or a serum total bilirubin greater than $3.0 \mathrm{mg} / \mathrm{dl}$ ). The control group comprised 30 healthy volunteers matched according to sex and age (mean age $58.2 \pm 8.9$ years).

\section{Enteral nutrition}

In the preoperative period standard enteral nutrition or immunonutrition was used as a supplementary diet 
for 5 days. The indication for pre-operative enteral nutrition treatment was the loss of body mass (greater than $6 \%$ within 2 months) and the extent of surgery (including the advancement of the tumour) [9]. Two enteral diets were used: a standard diet (Nutridrink ${ }^{\circledR}$, Nutricia Export BV, Zoetermeer, Holland ) and an immune-enhancing diet (FortiCare ${ }^{\circledR}$, Nutricia Export BV, Zoetermeer, Holland and Glutamine Plus ${ }^{\circledR}$, Fresenius Kabi). Each patient received 2 sachets (Glutamine Plus, $n=17$ ) or 3 containers (FortiCare, $n=9$ or Nutridrink, $n=24$ ) of diets per day according to the manufacturer's instructions. The immune-enhancing diets contained $20 \mathrm{~g}$ of glutamine, over $2 \mathrm{~g}$ of eicosapentaenoic acid (EPA) and $1.2 \mathrm{~g}$ of docosahexaenoic acid (DHA).

\section{Flow cytometry}

Blood samples were collected from the peripheral vein before $(-1)$ and after (day 0 ) preoperative nutrition and on post-operative days 1, 3 and 7. For staining of surface proteins $100 \mu \mathrm{l}$ of heparinized blood were incubated with $20 \mu \mathrm{l}$ of the following monoclonal antibodies: CD3 PE, CD95 FITC (Becton Dickinson Immunocytometry Systems; Becton Dickinson and Co, San Jose, California), CD120a PE (Immunotech, a Beckman Coulter Company 13009 Marseille, France) and their appropriate isotype-matched control antibodies. After 30 min incubation at room tempera-

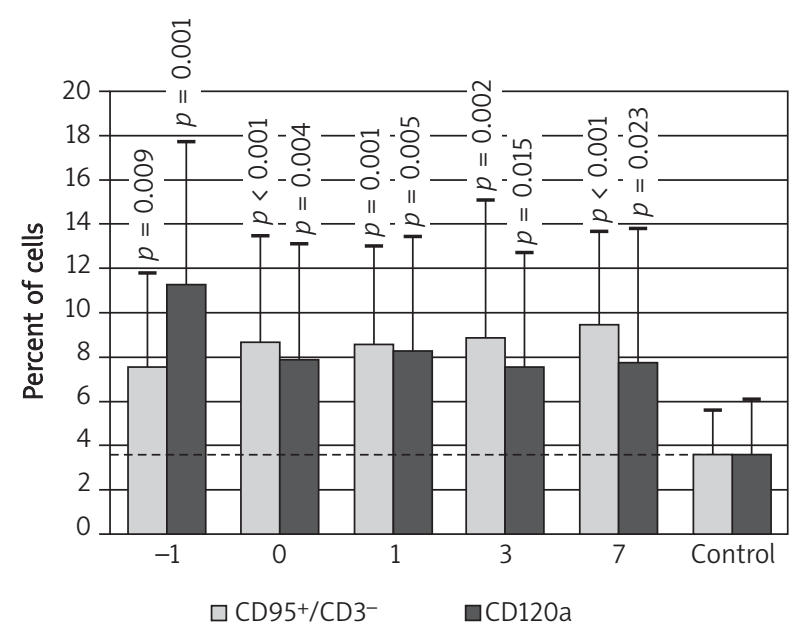

Fig. 1. Percentage of Fas $\left(\mathrm{CD}^{2} 5^{+/ \mathrm{CD}^{-}}{ }^{-}\right)$and TNFRI (CD120a) positive lymphocytes in the whole group of pancreatic cancer patients before and after surgery as compared with control group. Values are expressed as means \pm SD

Ryc. 1. Odsetek limfocytów Fas (CD95+/CD3-) i TNFRI (CD120a) pozytywnych w catej grupie chorych na raka trzustki przed operacja oraz po niej w porównaniu z grupą kontrolną. Wartości podano jako: średnia $\pm S D$ ture, red cells were lysed by the addition of FACS Lysing Solution (Becton Dickinson Biosciences, San Jose, California, USA) to the tubes. After $10 \mathrm{~min}$, samples were washed in PBS with $1 \%$ bovine serum albumin (BSA; Sigma Chemical $\mathrm{Co})$ and $0.1 \%$ sodium azide $\left(\mathrm{NaN}_{3}\right)$ and fixed with $1 \%$ paraformaldehyde (Sigma Chemical $\mathrm{Co}$ ).

To evaluate the intracellular expression of Bcl-2, $100 \mu \mathrm{l}$ of heparinized blood were lysed and permeabilized with BD FACS Permeabilizing Solution 2 (Becton Dickinson and $(\mathrm{C})$ for $10 \mathrm{~min}$. Next, samples were washed with PBS-BSA-NaN $\mathrm{Nan}_{3}$ and incubated with $20 \mu \mathrm{l}$ of Bcl-2 PE (Becton Dickinson and $\mathrm{Co}$ ) for $30 \mathrm{~min}$ at room temperature. Then, after washing with PBS-BSA-NaN $\mathrm{N}_{3}$, the samples were fixed with $1 \%$ paraformaldehyde.

The stained cells were acquired using the LSR instrument (Becton Dickinson) to detect two fluorescence parameters and two scatter parameters. Data were analysed using CellQuest ProSoftware version 9.2 (Becton Dickinson) and expressed as the percentage of lymphocytes with positive surfaces or intracellular pro- and anti-apoptotic protein expression (means \pm SD).

The protocol of the study was approved by the Medical University Ethics Committee.

\section{Statistical analysis}

Statistical analysis was performed using the StatSoft Statistica v.7.0 program. To compare the differences in lymphocyte percentage between groups and preoperative vs. postoperative results the Mann-Whitney or Wilcoxon signed-rank test with Bonferroni correction was used. Value of $p<0.05$ was defined as significant.

\section{Results}

In the whole group of pancreatic cancer patients (groups I and II) the percentage of lymphocytes with Fas $\left(\mathrm{CD}^{+} 5^{+} / \mathrm{CD}^{-}\right)$and TNFRI (CD120a) phenotypes was significantly higher before as well as after surgery as compared with the control group (Fig. 1). The percentage of Bcl-2-positive lymphocytes was significantly decreased on day 1 and 7 after surgery as compared with the control group (Fig. 2). There was no significant difference between preoperative and postoperative levels of $\mathrm{CD}^{+} 5^{+} \mathrm{CD}^{-}$and CD120a positive lymphocytes. Furthermore, no significant difference was found between the percentage of $\mathrm{CD}^{2} 5^{+} / \mathrm{CD}^{+}$lymphocytes in comparison with the control group (before and after surgery) whereas $\mathrm{CD}^{-} 5^{-} / \mathrm{CD}^{+}$positive cells were significantly decreased on day 1 after surgery (16.38 $\pm 10.3 \%$ vs. $30.4 \pm 14.9 \%$, $p=0.002$ ).

The immune-enhancing preoperative enteral nutrition including both glutamine and polyunsaturated fatty acids significantly increased the percentage of $\mathrm{CD} 5^{+} / \mathrm{CD}^{-}$and CD120a positive lymphocytes on day 3 after pancreatic 
resection as compared to the group of patients receiving preoperative standard enteral nutrition (Figs. 3, 4). There was also a tendency to increased percentage of $\mathrm{CD}^{\circ} 5^{+} / \mathrm{CD}^{-}$and $\mathrm{CD} 120$ a positive lymphocytes on day 7 after surgery in patients with preoperative immunonutrition $(p=0.05)$. Conversely, no significant difference was found in the percentages of $\mathrm{CD} 5^{+} / \mathrm{CD}^{+}$and $\mathrm{CD}^{-} 5^{-} / \mathrm{CD}^{+}$positive lymphocytes and the percentage of $\mathrm{Bcl}$-2-positive cells between the group of patients with immunonutrition versus standard nutrition before as well as after pancreas surgery.

\section{Discussion}

The survival rate after pancreatic cancer resection is still very low (10-30\% 5-year survival rate) and morbidity even in high-volume centres has remained at 30$50 \%$ [10]. Major surgical trauma under general anaesthesia induces an intracellular perturbation in peripheral lymphocytes, resulting in both up-regulation of death-signalling factors (Fas, FasL) and down-regulation of survival-signalling factors ( $\mathrm{Bcl}-2)$. The increased apoptosis of CD8 lymphocytes, excluding CD4 cells, seemed to be associated with a greater risk of post-surgical infections [11]. Our study clearly revealed (i) an increase in the percentage of lymphocytes with

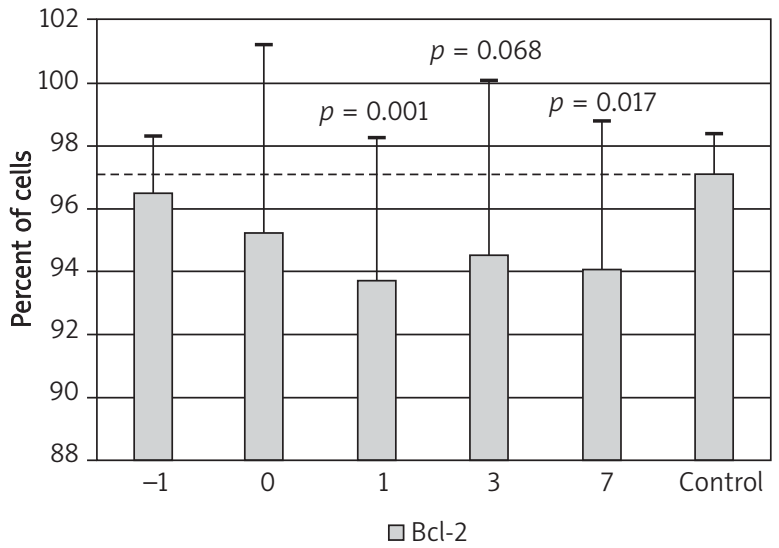

Fig. 2. Percentage of Bcl-2-positive lymphocytes in the whole group of pancreatic cancer patients before and after surgery as compared with control group. Values are expressed as means $\pm \mathrm{SD}$

Ryc. 2. Odsetek limfocytów Bcl-2 pozytywnych $w$ catej grupie chorych na raka trzustki przed operacja oraz po niej w porównaniu z grupa kontrolna. Wartości podano jako: średnia \pm SD

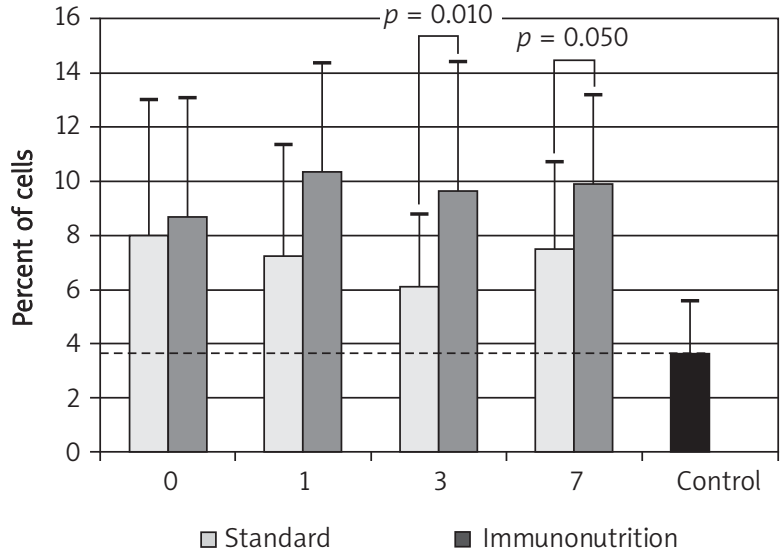

Fig. 3. Percentage of Fas (CD95+/CD3-) positive lymphocytes before and after surgery in pancreatic cancer patients who received preoperative enteral standard (group I) and immuneenhancing nutrition (group II). Values are expressed as means $\pm \mathrm{SD}$

Ryc. 3. Odsetek limfocytów Fas (CD95+/CD3-) pozytywnych przed operacja oraz po niej u chorych na raka trzustki otrzymujacych przedoperacyjne dojelitowe żywienie standardowe (grupa l) i żywienie wspomagajace odporność (grupa II). Wartości podano jako: średnia $\pm S D$

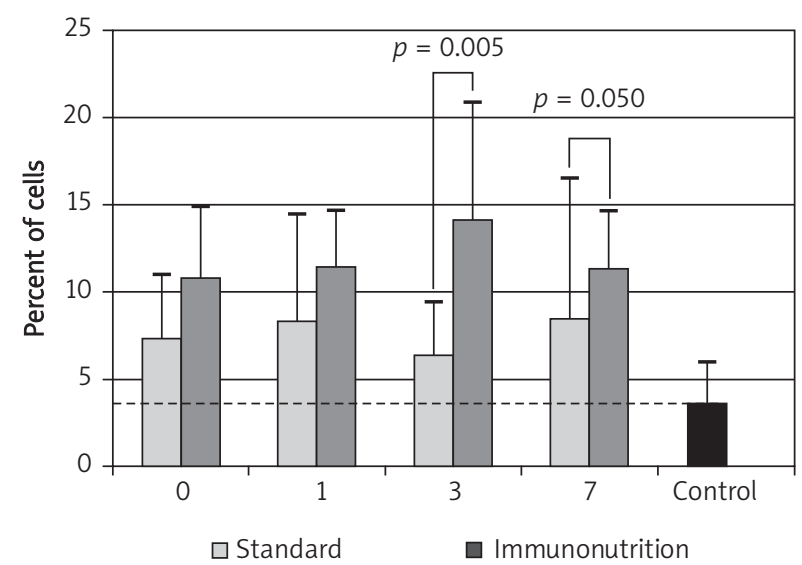

Fig. 4. Percentage of TNFRI (CD120a) positive lymphocytes before and after surgery in pancreatic cancer patients who received preoperative enteral standard (group I) and immuneenhancing nutrition (group II). Values are expressed as means $\pm \mathrm{SD}$

Ryc. 4. Odsetek limfocytów TNFRI (CD120a) pozytywnych przed operacja oraz po niej u chorych na raka trzustki otrzymujacych przedoperacyjne dojelitowe żywienie standardowe (grupa I) i żywienie wspomagające odporność (grupa II). Wartości podano jako: średnia $\pm S D$ 
proapoptotic protein expression (Fas and TNFRI), and (ii) significant decrease of anti-apoptotic protein expression (Bcl-2) of peripheral blood lymphocytes. It was observed especially in malnourished patients with cancer of the pancreas before as well as after surgery. These pathological alterations in apoptotic signalling pathway proteins may increase lymphocyte dysfunction, resulting in immune system suppression and higher lymphocyte susceptibility to undergo inappropriate apoptosis. Such immune disorders before major surgery may influence pancreatic cancer patients' susceptibility to infectious complications as well as to tumour metastasis in the early postoperative period.

One possible explanation of inappropriate changes in apoptotic signalling pathway proteins is related to immune system cells' malnutrition in pancreatic cancer patients. In our study disease-related malnutrition (the loss of body mass greater than $6 \%$ within 2 months) detected in $70 \%$ of patients was the indication for preoperative enteral nutrition treatment. In malnourished pancreatic cancer patients we used an immune-enhancing diet enriched with glutamine, and in a small group it also contained polyunsaturated fatty acids. It has been demonstrated that in a catabolic state, including multiple metabolic aberrations in cancer patients before and after major surgery, in trauma or sepsis low levels and insufficient production of immune-enhancing nutrients (e.g. glutamine $<0.42 \mathrm{nM}$ ) is associated with a higher susceptibility to infections, higher mortality and impairment of the immune response [12-14]. The lowered plasma glutamine availability contributes to the immunosuppression by compromised lymphocyte proliferation. Results of the study presented by Exner et al. [15] show that glutamine deprivation increases the susceptibility of human monocytic cells (U937 cells) to some (tumour necrosis factor $\alpha$, Fas ligand, heat shock, or UV irradiation) but not all inducers of apoptosis. A similar process may concern lymphocytes of malnourished patients with cancer of the pancreas. Other studies have revealed that parenteral and enteral administration of glutamine vs. standard feeding maintained lymphocyte numbers and function in patients at risk of immunosuppression or infection and improved patient outcome [16-18].

Our findings strongly suggest that up-regulation of pro-apoptotic signalling systems in lymphocytes of pancreatic cancer patients is very frequent. In pancreatic cancer patients the percentage of lymphocytes with Fas/CD95+/CD3 ${ }^{-}$and TNF-R1/CD120a phenotypes was significantly higher before as well as after surgery (as compared with the control group). Such lymphocyte phenotypes and significantly decreased $\mathrm{Bcl}-2$ intra- cellular expression after pancreatic cancer surgery may lead to inappropriate cell apoptosis. Apoptosis-inducing receptors of the TNFR superfamily such as Fas/CD95 or TNF-R1 exist at the cell surface as pre-formed trimers. Ligation of the death receptors leads to apoptosis through a common transcription/translation-independent pathway. The extensive apoptotic death of lymphocytes probably contributes to profound immunosuppression after pancreatic resection. As a response to major surgery we found that the percentage of $\mathrm{CD}^{-} 5^{-} / \mathrm{CD}^{+}$cells and lymphocytes with $\mathrm{Bcl}-2$ expression was decreased. It has been proved that proteins of the $\mathrm{Bcl}-2$ family function in the intrinsic death pathway, playing important roles in regulating the life and death of T lymphocytes [19]. In an experimental study, the deletion of $\mathrm{Bcl}-2$ results in rapid disappearance of naive $T$ cells [20]. Thus, downregulation of survival-signalling proteins of lymphocytes may influence the post-surgical outcome.

Finally, our study demonstrated that by using preoperative enteral immunonutrition we can modulate apoptotic signalling pathways and prevent the lymphocyte subsets decreasing after pancreatic resection as compared with standard nutritional support. In the majority of patients with immunonutrition, a glutamine-enriched diet was used. The small group of patients receiving unsaturated fatty acid does not permit any separate conclusion. There was a significant elevation in the percentage of Fas $\left(\mathrm{CD} 5^{+} / \mathrm{CD}^{-}\right)$and TNFRI (CD120a) lymphocytes after immunonutrition as compared with the standard diet. The changes in the percentage of cells with the death receptor family observed in our study may enhance antitumour activity (for instance by Fas and TNF-R1 mediated cytotoxicity), but also higher lymphocyte susceptibility to apoptosis after such immunonutrition should be considered. These results confirm the immunomodulatory effect of immune-enhancing enteral nutrition, but on the other hand may point to the pro-apoptotic influence of the pancreatic tumour.

In an experimental study, the presence of glutamine increased lymphoproliferation as well as Bcl-2 and CD95 expression, but decreased CD95L and activation-induced T-cell death [6]. The authors of that study suggested that glutamine protects activated human $T$ cells from apoptosis by up-regulating glutathione and $\mathrm{Bcl}-2$ levels and down-regulating both caspase- 3 and caspase- 8 activities. The mechanism by which glutamine protects cells from apoptosis is still unclear, but these observations suggest that glutamine possesses anti-apoptotic properties and supply of glutamine in malnourished patients is required for the immune system to function optimally. 


\section{Conclusions}

Our studies revealed the up-regulation of pro-apoptotic signalling systems in peripheral blood lymphocytes of malnourished patients with pancreatic cancer. These pathological alterations in apoptotic signalling pathway proteins may increase lymphocyte dysfunction and immune system suppression, especially after pancreatic resection. Preoperative enteral immunonutrition has a modulatory effect on apoptotic signalling pathways, but a clear anti-apoptotic property of such nutrition in pancreatic cancer patients is still questionable. Further research needs to be undertaken to examine the differences in the reaction of apoptotic signalling proteins to selected immunonutrients.

\section{Acknowledgments}

This work was supported by Projects No. 2 PO5B 059 28 and 3068B P01 funded by the Ministry of Science and Higher Education.

\section{References}

1. Yeo CJ, Cameron JL, Sohn TA, et al. Six hundred fifty consecutive pancreaticoduodenectomies in the 1990s: pathology, complications, and outcomes. Ann Surg 1997; 226: 248-57.

2. Halloran CM, Ghaneh P, Bosonnet L, et al. Complications of pancreatic cancer resection. Dig Surg 2002; 19: 138-46.

3. Alexakis N, Halloran C, Raraty M, et al. Current standards of surgery for pancreatic cancer. Br J Surg 2004; 91: 1410-27.

4. Serini S, Piccioni E, Merendino N, et al. Dietary polyunsaturated fatty acids as inducers of apoptosis: implications for cancer. Apoptosis 2009; 14: 135-52.

5. Dekoj T, Helton HS, Babcock TE. Decreased total Bcl-2 antiapoptotic protein level in pancreatic cancer (MIA PAA-2) cells incubated with n-3 fatty acids enhanced media suggests mitochondrial directed apoptosis. J Gatroenterol Surg 2005; 4: 604-12.

6. Chang WK, Yang KD, Chuang $\mathrm{H}$, et al. Glutamine protects activated human $\mathrm{T}$ cells from apoptosis by up-regulating glutathione and Bcl-2 levels. Clin Immunol 2002; 104: 151-60.

7. Gonzalez-Periz A, Planaguma A, Gronert K, et al. Docosahexaenoic acid (DHA) blunts liver injury by conversion to protective lipid mediators: protectin D1 and 17S-dydroxy-DHA. FASEB J 2006; 20: 2537-9.

8. Bannenberg GL, Chiang N, Ariel A, et al. Molecular circuitis of resolution: formation and actions of resolvins and protectins. J Immunol 2005; 174: 4345-55.

9. Weimann A, Braga M, Harsanyi L, et al. ESPEN Guidelines on Enteral Nutrition: surgery including organ transplantation. Clin Nutr 2006; 25: 224-44.

10. Strasberg SM, Drebin JA, Soper NJ. Evolution and current status of the Whipple procedure: an update for gastroenterologists. Gastroenterology 1997; 113: 983-94.

11. Delogu G, Moretti S, Antonucci A, et al. Apoptosis and surgical trauma: dysregulated expression of death and survival factors on peripheral lymphocytes. Arch Surg 2000; 135: 1141-7.
12. Coeffier M, Dechelotte P. The role of glutamine in intensive care unit patints: mechanisms of action and clinical outcome. Nutr Rev 2005; 63: 65-9.

13. Melis GC, Wenger N, Boelens PG, et al. Glutamine: recent developments in research on the clinical significance of glutamine. Curr Opin Clin Nutr Metab Care 2004; 7: 59-70.

14. Oudemans-van Straaten HM, Bosman RJ, Treskes M, et al. Plasma glutamine depletion and patient outcome in acute ICU admissions. Inten Care Med 2001; 27: 84-90.

15. Exner R, Weingartmann G, Eliasen MM, et al. Glutamine deficiency renders human monocytic cells more susceptible to specific apoptosis triggers. Surgery 2002; 131: 75-80.

16. Houdijk APJ, Rijnsburger ER, Jansen J, et al. Randomised trial of glutamine-enriched parenteral nutrion on infectious morbidity in patents with multiple trauma. Lancet 1998; 352: 772-6.

17. O’Riordain M, Fearo KC, Ross JA, et al. Glutamine supplemented parenteral nutrition enhances T-lymphocyte response in surgical patients undergoing colorectal resection. Ann Surg 1994; 220: 212-21.

18. Yoshida S, Matsiu M, Shirouzu Y, et al. Effects of glutamine supplements and radiochemotherapy on systemic immune and gut barrier function in patients with advanced esophageal cancer. Ann Surg 1998; 227: 485-91.

19. Droin, NM, Green DR. Role of Bcl-2 family members in immunity and disease. Biochim Biophys Acta 2004; 1644: 179-88.

20. Wojciechowski SP, Tripathi T, Bourdeau L, et al. Bim/Bcl-2 balance is critical for maintaining naive and memory $T$ cell homeostasis. J Exp Med 2007; 204: 1665-75. 